\title{
PENGARUH PROMOSI, KEPERCAYAAN DAN KESADARAN MEREK TERHADAP KEPUTUSAN NASABAH MENGGUNAKAN PRODUK TABUNGAN HAJI (MABRUR) BANK SYARIAH MANDIRI KCP. SAWANGAN KOTA DEPOK
}

\author{
Makhdaleva Hanura Tajudin, Ade Sofyan Mulazid \\ Fakultas Ekonomi dan Bisnis, UIN Syarif Hidayatullah Jakarta \\ E-mail:makhdaleva.hanura@gmail.com \\ E-mail: adesofyanmulazid@uinjkt.ac.id
}

\begin{abstract}
Effect Promotion, Trust and Brand Awareness Decision On Savings Products Customers Using The Hajj (Mabrur) Bank Syariah Mandiri KCP. Sawangan Kota Depok. The purpose of this study was to observe the effect of promotions, trust and brand awareness of the customer's decision to use a savings product Hajj (mabrur) case studies of Bank Syariah Mandiri KCP. Sawangan. This study using purposive sampling of 100 respondents, customers who use the product hajj savings (mabrur). The processed data in this study using multiple linear regression analysis. Based on the results, regression equation: $2,515+0.189 X 1+0.359 X 2+0.149 X 3$ $+e$, based on statistical data analysis, indicators in this study is valid and reliable variable. In the classical assumption, does not happen multikolinieritas and heteroskedastisitas, as well as the normal distribution of data. The results showed that partial and simultaneous sale of variable quality, trust and brand awareness significantly influence purchasing decisions.
\end{abstract}

Keywords: Promotions, Trust, Brand Awareness and Purchase Decision.

Abstrak. Pengaruh Promosi, Kepercayaan dan Kesadaran Merek Terhadap Keputusan Nasabah Menggunakan Produk Tabungan Haji (Mabrur) Bank Syariah Mandiri KCP. Sawangan Kota Depok. Tujuan dari penelitian ini adalah untuk melihat pengaruh promosi, kepercayaan dan kesadaran merek terhadap keputusan nasabah menggunakan produk tabungan haji (mabrur) studi kasus Bank Syariah Mandiri KCP. Sawangan Kota Depok. Penelitian ini menggunakan purposive sampling dengan 100 responden yaitu nasabah yang menggunakan produk tabungan haji (mabrur). Data yang diolah dalam penelitian ini menggunakan analisis regresi linear berganda. Berdasarkan hasil, diperoleh persamaan regresi: $2.515+0.189 X 1+$ $0.359 X 2+0.149 X 3+e$, berdasarkan analisis data statistik, indikator dalam penelitian ini valid dan variabel reliabel. Dalam uji asumsi klasik, tidak terjadi multikolinieritas dan heteroskedastisitas, serta data berdistribusi normal.Hasil penelitian menunjukkan bahwa secara parsial dan simultan variabel kualitas promosi, kepercayaan dan kesadaran merek berpengaruh signifikan terhadap keputusan pembelian.

Kata Kunci: Promosi, Kepercayaan, Kesadaran Merek dan Keputusan Pembelian. 


\section{Pendahuluan}

Ibadah haji merupakan salah satu Rukun Islam kelima bagi umat Islam, bahkan menjadi salah satu surah dalam Al-Qur'an (Sulaiman, 2007). Ibadah ini dilakukan dengan berkunjung dan melaksanakan beberapa kegiatan yang telah ditetapkan dibeberapa tempat di Arab Saudi pada suatu waktu tepatnya pada musim Haji (Bulan Dzulhijjah).

Menunaikan ibadah haji merupakan dambaan bagi setiap umat Islam diseluruh dunia, tidak terkecuali umat Islam di Indonesia. Indonesia merupakan negara dengan jumlah penduduk beragama Islam terbanyak di dunia berdasarkan populasi dengan jumlah umat Islam di Indonesia 199.959.285 jiwa atau 85,2\% dari jumlah penduduk Indonesia (www.republika.co.id, 9-1-2016). Kecenderungan umat Islam Indonesia untuk bisa menunaikan ibadah haji terus meningkat dari tahun ke tahun.

Keuntungan dari tabungan haji (mabrur) ini adalah setoran ringan, kemudahan dalam administrasi, bebas biaya administrasi, asuransi jiwa dan kecelakaan, online dengan Siskohat dan memberikan kebijaksanaan penarikan sesuai permintaan nasabah apabila nasabah sedang membutuhkan dana tersebut. Keuntungan lain dari BSM tabungan haji (mabrur) adalah mendapat dana talangan. Dana talangan sendiri merupakan pinjaman dana talangan dari bank kepada nasabah khusus untuk menutupi kekurangan dana untuk memperoleh kursi (seat) haji dan pada saat pelunasan BPIH (www.syariahmandiri.co.id, 2010).

Berikut adalah data pendapatan ujrah (fee) dana talangan haji Bank Syariah Mandiri tahun 2011-2015.

Tabel 1

Data Pendapatan Ujrah (fee) Dana Talangan Haji Bank Syariah Mandiri

\begin{tabular}{|c|c|}
\hline Tahun & Pendapatan Ujrah (Fee) Dana Talangan Haji \\
\hline 2011 & 324.807 .690 .742 \\
\hline 2012 & 441.932 .235 .502 \\
\hline 2013 & 374.659 .038 .321 \\
\hline 2014 & 249.321 .447 .358 \\
\hline 2015 & 62.639 .394 .092 \\
\hline
\end{tabular}

Sumber: Laporan Keuangan BSM (syariahmandiri.co.id, 2015). 
Makhdaleva H, Ade Sofyan M: Pengaruh Promosi...

Tabel 1 menjelaskan bahwa pada tahun 2011-2012, pendapatan ujrah (fee) dana talangan haji mengalami peningkatan. Kecuali, pada tahun 2013-2015 pendapatan ujrah (fee) dana talangan haji terus mengalami penurunan. Penyebab penurunan ini tak lain adalah pada tahun 2013 adanya indikasi gejolak ekonomi dalam pemerintahan seperti kenaikan harga BBM yang terjadi pada Juni 2013 yang membuat harga-harga menjadi mahal atau tinggi (Wartoyo, 2013). Sedangkan pada 2014 Dewan Syariah Nasional Majelis Ulama Indonesia (DSN-MUI) menerbitkan Fatwa 29/2002 tentang pembiayaan pengurusan haji lembaga keuangan syariah (LKS), BSM menghentikan talangan haji sejak 2014. Penghentian ini memang memengaruhi pendapatan BSM. Sedangkan pada tahun 2015 strategi bisnis BSM yang mengalami perubahan. Jika semula BSM lebih mengandalkan produk konsumtif, kini BSM mulai berubah dengan lebih fokus pada pembiayaan ke sektor riil seperti mikro, usaha kecil menengah (UKM) dan lain-lain (www.republika.co.id, 5-3-2016).

Bank Syariah Mandiri melakukan berbagai strategi untuk meningkatkan produk tabungan haji (mabrur), yaitu meningkatkan kerja sama dengan biro travel haji, mengikuti pameran tour dan travel umrah atau haji, memberikan suvenir kepada calon jamaah haji, melakukan promosi berupa standing banner, brosur, spanduk di cabang-cabang BSM, serta melakukan promosi melalui media cetak dan elektronik (Syukriyah, 2015).

Melihat banyaknya kompetitor antar bank yang diberikan kepercayaan sebagai mediator Biaya Penyetoran Ibadah Haji (BPIH). Dengan demikian, Bank Syariah Mandiri berlomba untuk memberikan fasilitas dan kenyamanan bagi nasabahnya dengan mengeluarkan produk tabungan haji (mabrur).

\section{Kajian Pustaka}

\section{Tabungan Haji (Mabrur) Bank Syariah Mandiri}

Perbankan menjadi salah satu alternatif sistem perbankan yang kredibel dan dapat diminati oleh seluruh golongan masyarakat Indonesia tanpa terkecuali, sehingga Bank Syariah Mandiri menyediakan berbagai jenis produk yang dapat dipilih oleh masyarkat, salah satunya adalah BSM tabungan haji (mabrur).

Tabungan haji adalah suatu program tabungan yang ditujukan kepada para nasabah bank yang memiliki cita-cita untuk berangkat ke tanah suci. Dalam program 
Islamiconomic: Jurnal Ekonomi Islam

Vol.8 No.1 Januari - Juni 2017

tabungan haji, para calon jamaah haji selain mendapatkan tabungan, calon jamaah haji juga akan mendapatkan asuransi yang akan mengcover mereka hingga tabungan tersebut cukup untuk dipakai menunaikan ibadah ke tanah suci tersebut. (www.bisnisfranchiseonline.com, 2015).

Menurut PT. Bank Syariah Mandiri tabungan haji (mabrur) adalah produk tabungan bagi umat Islam yang mempunyai rencana menunaikan ibadah haji (www.syariahmandiri.co.id, 2016). Tabungan haji (mabrur) memberikan banyak kemudahan dan manfaat untuk persiapan ibadah ke tanah suci. Ada beberapa fasilitas, keunggulan dan kelebihan produk tabungan ini yang menjadi andalan Bank Syariah Mandiri.

\section{Promosi}

Pengertian promosi menurut Kotler dan Armstrong (2012:76), "Promotion means activities that communicate the merits of the product and persuade target customers to buy it", artinya promosi merupakan kegiatan yang mengomunikasikan manfaat dari sebuah produk dan membujuk target konsumen untuk membeli produk tersebut.

Menurut Rangkuti (2010:50), promosi adalah kegiatan penjualan dan pemasaran dalam rangka menginformasikan dan mendorong permintaan terhadap produk, jasa dan ide dari perusahaan dengan cara mempengaruhi konsumen agar mau membeli produk dan jasa yang dihasilkan oleh perusahaan.

Setelah melihat definisi-definisi tersebut di atas, maka dapat diambil kesimpulan bahwa promosi adalah kegiatan mengkomunikasikan atau menginformasikan manfaat dari sebuah produk dan jasa kepada konsumen untuk mendorong dan membujuk konsumen untuk membeli produk dan jasa tersebut.

\section{Kepercayaan}

Menurut Kotler (2009), kepercayaan adalah kesediaan perusahaan untuk bergantung pada mitra bisnis. Kepercayaan tergantung pada sejumlah faktor antar pribadi dan antar organisasi, seperti kompetensi, integritas, kejujuran, dan kebaikan hati perusahaan. Sedangkan menurut Morgan dan Hunt dalam Suhardi (2006) mendefinisikan kepercayaan sebagai suatu kondisi ketika salah satu pihak yang 
Makhdaleva H, Ade Sofyan M: Pengaruh Promosi...

terlibat dalam proses pertukaran yakin dengan kehandalan dan integritas pihak yang lain.

Kepercayaan konsumen adalah semua pengetahuan yang dimiliki konsumen dan semua kesimpulan yang dibuat konsumen tentang objek, atribut dan manfaatnya (Sunarto, 2006:153).

\section{Kesadaran Merek}

Kesadaran merek adalah kesanggupan seorang calon pembeli untuk mengenali, mengingat kembali suatu merek sebagai bagian dari suatu kategori produk tertentu (Durianto, dkk., 2004: 57).

Aaker (2010) dalam Uslu., et al 2013) mendefinisikan kesadaran merek (brand awareness) sebagai kemampuan yang dimiliki oleh pembeli potensial untuk mengenali dan mengingat bahwa merek adalah anggota dari kategori produk tertentu. Menurut Keller (2004) kesadaran merek dapat dikarakteristikan menurut kedalaman dan keluasannya. Kedalaman dari kesadaran merek berhubungan dengan kemungkinan merek dapat dikenal atau diingat kembali. Sedangkan keluasan kesadaran merek berhubungan dengan keanekaragaman situasi pembelian dan konsumsi sebuah merek diingat.

\section{Keputusan Pembelian}

Menurut Kotler dan Armstrong (2012:157) "Consumer buyer behavior refers to the buying behavior of final consumers-individuals and households that buy goods and services for personal consumption," pengertian tersebut dapat diartikan bahwa perilaku keputusan pembelian mengacu pada perilaku pembelian akhir dari konsumen, baik individual, maupun rumah tangga yang membeli barang dan jasa untuk konsumsi pribadi. Sedangkan menurut Kotler dan Keller (2009:240) menyatakan bahwa, Keputusan pembelian adalah konsumen membentuk niat untuk membeli merek yang paling disukai.

\section{Hubungan Promosi dengan Keputusan Nasabah}

Promosi menjadi faktor penting dalam mempengaruhi keputusan menggunakan suatu produk. Pengaruh promosi yang bagus dan dengan intensitas yang tinggi akan 
Islamiconomic: Jurnal Ekonomi Islam

Vol.8 No.1 Januari - Juni 2017

menjadikan koonsumen mengenal dan ada rasa penasaran terhadap produk yang dipromosikan. Promosi sendiri sarana untuk membangun kepercayaan dan penilaian konsumen terhadap produk, yaitu dengan membina hubungan erat antara produsen dengan konsumen melalui pendekatan strategi promosi yang tepat (Kopalle dan Lehmann, 1995).

\section{Hubungan Kepercayaan dengan Keputusan Nasabah}

Kepercayaan menjadi faktor penting dalam mempengaruhi keputusan menggunakan suatu produk. Kepercayaan adalah kemauan seseorang untuk bertumpu pada orang lain di mana kita memiliki keyakinan padanya. Kepercayaan merupakan kondisi mental yang didasarkan oleh situasi seseorang dan konteks sosialnya. Ketika seseorang mengambil suatu keputusan, ia akan lebih memilih keputusan berdasarkan pilihan orang-orang yang lebih dapat ia percaya dari pada yang kurang dipercayai (Armayanti, 2011).

\section{Hubungan Kesadaran Merek dengan Keputusan Nasabah}

Kesadaran Merek menjadi faktor penting dalam mempengaruhi keputusan menggunakan suatu produk. Menurut Aaker (1991) kesadaran merek (brand awareness) mempengaruhi rasa percaya diri pelanggan atas keputusan pembelian dengan mengurangi tingkat risiko yang dirasakan atas suatu merek yang diputuskan untuk dibeli. Kesadaran merek (brand awareness) memainkan peranan penting dalam pengambilan keputusan konsumen mengenai pertimbangan merek mana yang akan digunakan (Macdonal., et al 2003).

\section{Penelitian Terdahulu}

\begin{tabular}{|c|c|c|c|c|c|}
\hline No & $\begin{array}{l}\text { Nama dan } \\
\text { Tahun } \\
\text { Penelitian }\end{array}$ & $\begin{array}{l}\text { Judul } \\
\text { Penelitian }\end{array}$ & Persamaan & Perbedaan & $\begin{array}{l}\text { Hasil } \\
\text { Penelitian }\end{array}$ \\
\hline 1 & $\begin{array}{l}\text { Monang Ranto } \\
\text { Tambunan dan } \\
\text { Inggrita Gusti } \\
\text { Sari Nasution } \\
\text { Jurnal Ekonomi } \\
\text { dan Keuangan } \\
\text { Vol.1, No.3, }\end{array}$ & $\begin{array}{l}\text { Analisis } \\
\text { Faktor-faktor } \\
\text { Yang } \\
\text { Mempengaru } \\
\text { hi Keputusan } \\
\text { Nasabah } \\
\text { Menabung Di } \\
\text { Bank BCA }\end{array}$ & $\begin{array}{l}\text { Menggunakan } \\
\text { variabel } \\
\text { promosi } \\
\text { sebagai } \\
\text { variabel } \\
\text { independen } \\
\text { dan keputusan } \\
\text { pembelian }\end{array}$ & $\begin{array}{l}\text { Terdapat pada } \\
\text { variabel yang } \\
\text { mempengaruhi } \\
\text { keputusan } \\
\text { pembelian. } \\
\text { Peneliti tersebut } \\
\text { menggunakan } \\
\text { produk, }\end{array}$ & $\begin{array}{l}\text { 1. variabel produk } \\
\text { berpengaruh positif } \\
\text { dan signifikan } \\
\text { terhadap keputusan } \\
\text { nasabah. } \\
\text { 2. variabel pelayanan } \\
\text { berpengaruh positif } \\
\text { dan signifikan }\end{array}$ \\
\hline
\end{tabular}


Makhdaleva H, Ade Sofyan M: Pengaruh Promosi...

\begin{tabular}{|c|c|c|c|c|c|}
\hline & Februari 2013 & $\begin{array}{l}\text { Kota Medan } \\
\text { (Studi Kasus } \\
\text { Etnis Cina). }\end{array}$ & $\begin{array}{l}\text { sebagai } \\
\text { variabel } \\
\text { dependen. } \\
\text { Serta metode } \\
\text { penelitian } \\
\text { regresi liner } \\
\text { berganda. } \\
\text { Penelitian studi } \\
\text { ini bertempat } \\
\text { di bank. }\end{array}$ & $\begin{array}{l}\text { pelayanan, dan } \\
\text { kredibilitas } \\
\text { sebagai variabel } \\
\text { independen. }\end{array}$ & $\begin{array}{l}\text { terhadap keputusan } \\
\text { nasabah. } \\
\text { 3. variabel promosi } \\
\text { berpengaruh positif } \\
\text { tetapi tidak } \\
\text { signifikan terhadap } \\
\text { keputusan nasabah. } \\
\text { 4. variabel lokasi } \\
\text { berpengaruh positif } \\
\text { tetapi tidak } \\
\text { signifikan terhadap } \\
\text { keputusan nasabah. } \\
\text { 5ariabel kredibilitas } \\
\text { berpengaruh positif } \\
\text { dan signifikan } \\
\text { terhadap keputusan } \\
\text { nasabah. }\end{array}$ \\
\hline 2 & $\begin{array}{l}\text { Ahmad Muanas } \\
\text { dan Suherman } \\
\text { Jurnal Ilmu \& } \\
\text { Riset } \\
\text { Manajemen Vol. } \\
\text { 3, No. } 12 \\
\text { (2014) }\end{array}$ & $\begin{array}{l}\text { Pengaruh } \\
\text { Produk, } \\
\text { Harga dan } \\
\text { Promosi } \\
\text { Terhadap } \\
\text { Keputusan } \\
\text { Pembelian } \\
\text { Mobil Buana } \\
\text { Indomobil } \\
\text { Trada. }\end{array}$ & $\begin{array}{l}\text { Menggunakan } \\
\text { variabel } \\
\text { promosi } \\
\text { sebagai } \\
\text { variabel } \\
\text { independen } \\
\text { dan keputusan } \\
\text { pembelian } \\
\text { sebagai } \\
\text { variabel } \\
\text { dependen. } \\
\text { Serta metode } \\
\text { penelitian } \\
\text { regresi liner } \\
\text { berganda. }\end{array}$ & $\begin{array}{l}\text { Terdapat variabel } \\
\text { yang } \\
\text { mempengaruhi } \\
\text { keputusan } \\
\text { pembelian. } \\
\text { Peneliti tersebut } \\
\text { menggunakan } \\
\text { produk dan harga } \\
\text { sebagai variabel } \\
\text { independen. } \\
\text { Penelitian ini studi } \\
\text { di pembelian } \\
\text { mobil. }\end{array}$ & 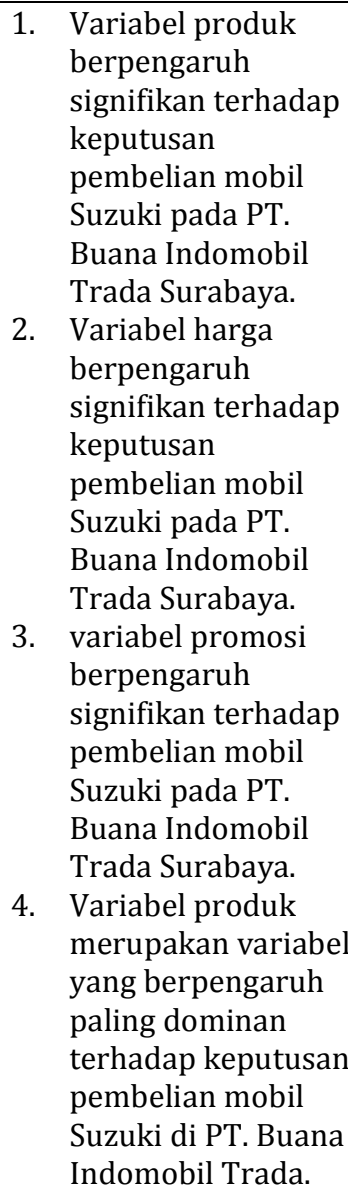 \\
\hline 3 & $\begin{array}{l}\text { Andy Putra } \\
\text { Suryadi dan } \\
\text { Riyandi } \\
\text { Mahkota, Imam } \\
\text { Junal }\end{array}$ & $\begin{array}{l}\text { Pengaruh } \\
\text { Kepercayaan } \\
\text { dan } \\
\text { Kenyamanan } \\
\text { Terhadap } \\
\text { Keputusan }\end{array}$ & $\begin{array}{l}\text { Menggunakan } \\
\text { variabel } \\
\text { kepercayaan } \\
\text { sebagai } \\
\text { variabel } \\
\text { independen }\end{array}$ & $\begin{array}{l}\text { Terdapat pada } \\
\text { variabel yang } \\
\text { mempengaruhi } \\
\text { keputusan } \\
\text { pembelian. } \\
\text { Peneliti tersebut }\end{array}$ & $\begin{array}{l}\text { 1. } \text { Variabel } \\
\text { kepercayaan } \\
\text { memiliki pengaruh } \\
\text { yang signifikan } \\
\text { terhadap keputusan } \\
\text { pembelian online. }\end{array}$ \\
\hline
\end{tabular}


Islamiconomic: Jurnal Ekonomi Islam

Vol.8 No.1 Januari - Juni 2017

\begin{tabular}{|c|c|c|c|c|c|}
\hline & $\begin{array}{l}\text { Administrasi } \\
\text { Bisnis (JAB) } \\
\text { Vol. 8, No. } 2 \\
\text { Maret 2014 }\end{array}$ & $\begin{array}{l}\text { Pembelian } \\
\text { Online (Studi } \\
\text { Pada } \\
\text { Pelanggan } \\
\text { Website Ride } \\
\text { In). }\end{array}$ & $\begin{array}{l}\text { dan keputusan } \\
\text { pembelian } \\
\text { sebagai } \\
\text { variabel } \\
\text { dependen. } \\
\text { Serta metode } \\
\text { penelitian } \\
\text { regresi liner } \\
\text { berganda. }\end{array}$ & $\begin{array}{l}\text { menggunakan } \\
\text { kenyamanan, } \\
\text { sebagai variabel } \\
\text { independen. Studi } \\
\text { penelitian ini } \\
\text { pembelin secara } \\
\text { online. }\end{array}$ & $\begin{array}{l}\text { 2. } \text { Variabel } \\
\text { kenyamanan } \\
\text { memiliki pengaruh } \\
\text { yang signifikan } \\
\text { terhadap keputusan } \\
\text { pembelian online. }\end{array}$ \\
\hline 4 & $\begin{array}{l}\text { Ngakan Putu } \\
\text { Surya Adi } \\
\text { Dharma dan I } \\
\text { Putu Gde } \\
\text { Sukaatmadja } \\
\text { E-Jurnal } \\
\text { Manajemen } \\
\text { Unud, Vol. 4, } \\
\text { No.10, } \\
\text { 2015:3228- } \\
3255 \\
\text { ISSN:2302- } \\
8912\end{array}$ & $\begin{array}{l}\text { Pengaruh } \\
\text { Citra Merek, } \\
\text { Kesadaran } \\
\text { Merek, dan } \\
\text { Kulitas } \\
\text { Produk } \\
\text { Terhadap } \\
\text { Keputusan } \\
\text { Membeli } \\
\text { Produk Apple. }\end{array}$ & $\begin{array}{l}\text { Menggunakan } \\
\text { variabel } \\
\text { kesadaran } \\
\text { merek sebagai } \\
\text { variabel } \\
\text { independen } \\
\text { dan keputusan } \\
\text { pembelian } \\
\text { sebagai } \\
\text { variabel } \\
\text { dependen. } \\
\text { Serta metode } \\
\text { penelitian } \\
\text { regresi liner } \\
\text { berganda. }\end{array}$ & $\begin{array}{l}\text { Terdapat pada } \\
\text { variabel yang } \\
\text { mempengaruhi } \\
\text { keputusan } \\
\text { pembelian. } \\
\text { Peneliti tersebut } \\
\text { menggunakan } \\
\text { citra merek, } \\
\text { kualitas } \\
\text { produksebagai } \\
\text { variabel } \\
\text { independen. Studi } \\
\text { penelitian ini } \\
\text { pembelin secara } \\
\text { online. Produk } \\
\text { yang diteliti } \\
\text { barang bukan jasa. }\end{array}$ & $\begin{array}{l}\text { 1. Citra merek (brand } \\
\text { image) } \\
\text { berpengaruh } \\
\text { positif dan } \\
\text { signifikan terhadap } \\
\text { keputusan } \\
\text { pembelian produk } \\
\text { Apple. } \\
\text { 2. Kesadaran merek } \\
\text { (brand awareness) } \\
\text { berpengaruh } \\
\text { positif dan } \\
\text { signifikan terhadap } \\
\text { keputusan } \\
\text { pembelian produk } \\
\text { Apple. } \\
\text { Kualitas produk } \\
\text { (produk quality) } \\
\text { berpengaruh } \\
\text { secara positif dan } \\
\text { signifikan terhadap } \\
\text { keputusan } \\
\text { pembelian produk } \\
\text { Apple. }\end{array}$ \\
\hline 5 & $\begin{array}{l}\text { Rika Yulianti, } \\
\text { Marijati Sangen } \\
\text { dan Ahmad } \\
\text { Rivani } \\
\text { Jurnal } \\
\text { Wawasan } \\
\text { Manajemen, } \\
\text { Vol. 4, Nomor 2, } \\
\text { Juni 2016 }\end{array}$ & $\begin{array}{l}\text { Pengaruh } \\
\text { Nilai-nilai } \\
\text { Agama, } \\
\text { Kualitas } \\
\text { Layanan, } \\
\text { Promosi, dan } \\
\text { Kepercayaan } \\
\text { Terhadap } \\
\text { Keputusan } \\
\text { Menjadi } \\
\text { Nasabah } \\
\text { Bank Syariah } \\
\text { di } \\
\text { Banjarmasin. }\end{array}$ & $\begin{array}{l}\text { Menggunakan } \\
\text { variabel } \\
\text { promosi dan } \\
\text { kepercayaan } \\
\text { sebagai } \\
\text { variabel } \\
\text { independen } \\
\text { dan keputusan } \\
\text { pembelian } \\
\text { sebagai } \\
\text { variabel } \\
\text { dependen. } \\
\text { Serta metode } \\
\text { penelitian } \\
\text { regresi liner } \\
\text { berganda. Studi } \\
\text { yang di } \\
\text { gunakan juga } \\
\text { nasabah bank } \\
\text { syariah. }\end{array}$ & $\begin{array}{l}\text { Terdapat pada } \\
\text { variabel yang } \\
\text { mempengaruhi } \\
\text { keputusan } \\
\text { pembelian. } \\
\text { Peneliti tersebut } \\
\text { menggunakan } \\
\text { nilai-nilai agama, } \\
\text { kualitas layanan } \\
\text { sebagai variabel } \\
\text { independen. }\end{array}$ & 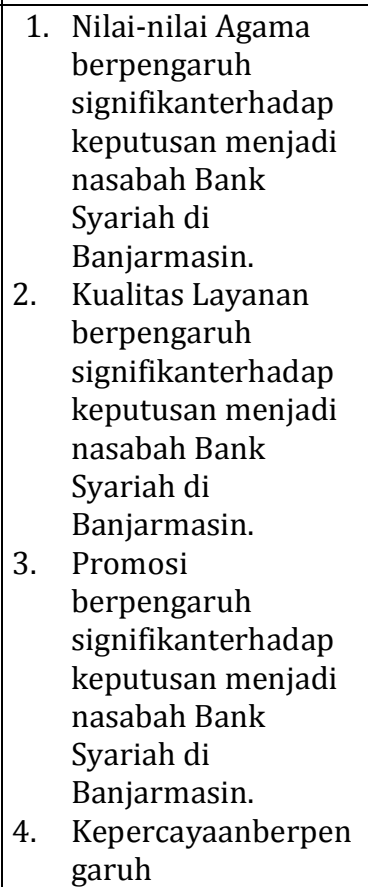 \\
\hline
\end{tabular}


Makhdaleva H, Ade Sofyan M: Pengaruh Promosi...

\begin{tabular}{|c|c|c|c|c|c|}
\hline & & & & & $\begin{array}{l}\text { signifikanterhadap } \\
\text { keputusan menjadi } \\
\text { nasabah Bank } \\
\text { Syariah di } \\
\text { Banjarmasin. }\end{array}$ \\
\hline 6 & $\begin{array}{l}\text { Laely Hidayah } \\
\text { dan Bulan } \\
\text { Prabawani } \\
(2016)\end{array}$ & $\begin{array}{l}\text { Pengaruh } \\
\text { Suku Bunga, } \\
\text { Pelayanan } \\
\text { dan } \\
\text { Kesadaran } \\
\text { Merek (Brand } \\
\text { Awareness) } \\
\text { Terhadap } \\
\text { Keputusan } \\
\text { Pengambilan } \\
\text { KPR (Studi } \\
\text { Pada Nasabah } \\
\text { PT Bank } \\
\text { Tabungan } \\
\text { Negara KC. } \\
\text { Semarang). }\end{array}$ & $\begin{array}{l}\text { Menggunakan } \\
\text { variabel } \\
\text { kesadaran } \\
\text { merek sebagai } \\
\text { variabel } \\
\text { independen } \\
\text { dan keputusan } \\
\text { pembelian } \\
\text { sebagai } \\
\text { variabel } \\
\text { dependen. } \\
\text { Serta metode } \\
\text { penelitian } \\
\text { regresi liner } \\
\text { berganda. Studi } \\
\text { produk KPR }\end{array}$ & $\begin{array}{l}\text { Terdapat pada } \\
\text { variabel yang } \\
\text { mempengaruhi } \\
\text { keputusan } \\
\text { pembelian. } \\
\text { Peneliti tersebut } \\
\text { menggunakan } \\
\text { suku bunga dan } \\
\text { pelayanan sebagai } \\
\text { variabel } \\
\text { independen. }\end{array}$ & $\begin{array}{l}\text { 1. Variabel Suku } \\
\text { Bunga memiliki } \\
\text { pengaruh paling } \\
\text { besar sebesar } \\
10,7 \% \\
\text { 2. Variabel Pelayanan } \\
\text { memiliki pengaruh } \\
\text { sebesar 5,5\% } \\
\text { 3. Variabel Kesadaran } \\
\text { Merek memiliki } \\
\text { pengaruh sebesar } \\
5,7 \%\end{array}$ \\
\hline
\end{tabular}

\section{Hipotesis}

Hipotesis yang diajukan sebagai jawaban sementara terhadap permasalahan yang diajukan dalam penelitian ini adalah sebagai berikut:

1. Ho : $\beta 1=0$; tidak terdapat pengaruh antara promosi terhadap keputusan menabung produk tabungan haji (mabrur).

Ha : $\beta 1 \neq 0$; terdapat pengaruh antara promosi terhadap proses keputusan menabung produk tabungan haji (mabrur).

2. Ho : $\beta 2=0$; tidak terdapat pengaruh antara kepercayaan terhadap proses keputusan menabung produk tabungan haji (mabrur).

Ha : $\beta 2 \neq 0$; terdapat pengaruh antara kepercayaan terhadap proses keputusan menabung produk tabungan haji (mabrur).

3. Ho : $\beta 3=0$; tidak terdapat pengaruh antara kesadaran merek terhadap proses keputusan menabung produk tabungan haji (mabrur).

Ha : $\beta 3 \neq 0$; terdapat pengaruh antara kesadaran merek terhadap proses keputusan menabung produk tabungan haji (mabrur).

4. Ho : $\beta 1,2,3=0$; tidak terdapat pengaruh antara promosi, kepercayaan, dan kesadaran merek terhadap proses keputusan menabung produk tabungan haji (mabrur). 


\section{Metodologi Penelitian}

Populasi pada penelitian ini adalah nasabah tabungan haji (mabrur) Bank Syariah Mandiri KCP. Sawangan Kota Depok. Teknik pengambilan sampel yang digunakan oleh penulis adalah Non probability Sampling, yaitu teknik pengambilan sampel yang tidak memberi peluang atau kesempatan sama bagi setiap unsur atau anggota populasi untuk dipilih menjadi sampel (Sugiyono, 2015:81). Teknik pengambilan sampel yang digunakan oleh penulis adalah metode sampling purposive, yaitu teknik penentuan sampel sumber data dengan pertimbangan tertentu (Sugiyono, 2015:82). Dengan demikian, pertimbangan pengambilan sampel dalam penelitian ini adalah responden merupakan nasabah tabungan haji (mabrur) Bank Syariah Mandiri yang melakukan pembukuan rekening di KCP. Sawangan Kota Depok.

Untuk mendapatkan data yang diperlukan, peneliti menggunakan instrumen berupa kuesioner yang diberikan kepada nasabah yang menggunakan produk tabungan haji (mabrur) Bank Syariah Mandiri KCP. Sawangan Kota Depok. Dalam kuesioner ini, penulis menggunakan skala likert, Skala likert digunakan untuk mengukur sikap, pendapat dan persepsi seseorang atau sekelompok orang tentang fenomena sosial (Sugiyono, 2015:93). Skala likert yang digunakan dalam penelitian ini, yaitu menggunakan skor 1-5.

\section{Teknik Analisis Data}

\section{Uji Asumsi Klasik}

\section{Uji Normalitas}

Menurut Ghozali (2011:147) uji normalitas bertujuan apakah dalam model regresi variabel dependen (terikat) dan variabel independen (bebas) mempunyai kontribusi atau tidak. Penelitian yang menggunakan metode yang lebih handal untuk menguji data mempunyai distribusi normal atau tidak yaitu dengan melihat Normal Probability Plot. Model regresi yang baik adalah data distribusi normal atau mendekati normal, untuk mendeteksi normalitas dapat dilakukan dengan melihat penyebaran data (titik) pada sumbu diagonal grafik. Terdapat dua cara untuk mendeteksi apakah residual berdistribusi normal atau tidak yaitu dengan analisis grafik dan uji statistik (uji Kolmogrov-smirnov). 
Makhdaleva H, Ade Sofyan M: Pengaruh Promosi...

\section{Uji Multikolinearitas}

Untuk mendeteksi ada atau tidaknya multikolonieritas di dalam model regresi adalah sebagai berikut (Ghozali, 2016:103). Mutikolonieriitas dilihat dari nilai tolerance dan lawannya, variance inflation factor (VIF). Dalam pengertian sederhana setiap variabel bebas menjadi variabel terikat dan diregresi terhadap variabel bebas lainnya. Nilai cutoff yang umum dipakai untuk menunjukkan adanya multikolonieritas adalah nilai Tolerance $<0.10$ atau sama dengan nilai VIF $>10$.

\section{Uji Heterokedastisitas}

Uji heteroskedastisitas bertujuan menguji apakah dalam model regresi terjadi ketidaksamaan varience dari residual suatu pengamatan ke penagamatan yang lainnya, jika variance dari residual suatu pengamatan ke pengamatan tetap, maka disebut Homoskedastisitas dan jika berbeda disebut Heteroskedastisitas. Model regresi yang baik adalah yang Homoskedastisitas atau tidak terjadi Heteroskedastisitas (Ghozali, 2016: 134).

\section{Uji Regresi Linier Berganda}

Analisis regresi pada dasarnya adalah studi mengenai ketergantungan variable dependen (terikat) dengan satu atau lebih variabel independen (bebas), dengan tujuan untuk mengistemasi dan memprediksi rata-rata populasi atau nilai ratarata populasi atau nilai rata-rata variabel dependen berdasarkan nilai variable independen yang diketahui (Gujarati, 2003 dalam Imam Ghozali, 2016:93).

\section{Uji Hipotesis}

Dalam pengujian hipotesis peneliti melakukan uji secara parsial yaitu Uji statistik t pada dasarnya menunjukkan seberapa jauh pengaruh satu variabel bebas (independen) secara individual dalam menerangkan variasi variabel terikat (dependen), dan uji secara simultan Uji F menguji joint hipotesis bahwa b1, b2, dan b3 secara simultan sama dengan nol (Ghozali, 2016: 97). 


\section{Uji Koefisien Determinasi $\left(R^{2}\right)$}

Koefisien determinasi $\left(\mathrm{R}^{2}\right)$ pada intinya mengukur seberapa jauh kemampuan model dalam menerangkan variasi variabel dependen. Nilai koefisien determinasi adalah antara nol dan satu. Nilai $\mathrm{R}^{2}$ yang kecil berarti kemampuan variabel-variabel bebas (independent) dalam menjelaskan variasi variabel terikat (dependent) amat terbatas.

\section{Pembahasan Hasil Penelitian}

\section{Hasil Distribusi Jawaban Responden}

\section{Distribusi Jawaban Responden Mengenai Promosi (X1).}

Variabel (X1) pada penelitian ini diukur melalui 8 pertanyaan yang disebarkan ke 100 responden dan mempresentasikan indikator-indikator dari variabel tersebut. Hasil tanggapan terhadap promosi dijelaskan pada tabel berikut:

\begin{tabular}{|c|l|c|c|c|c|c|c|c|}
\hline No. & \multicolumn{1}{|c|}{ PROMOSI } & STS & TS & N & S & SS & Total \\
\hline 1 & $\begin{array}{l}\text { Periklanan (Advertising) } \\
\text { Adanya brosur produk } \\
\text { tabungan haji (mabrur) yang } \\
\text { disediakan di Bank Syariah } \\
\text { Mandiri. }\end{array}$ & 0 & 0 & 7 & 54 & 39 & 100 \\
\hline 2 & $\begin{array}{l}\text { Bank Syariah Mandiri } \\
\text { memasang spanduk bank di } \\
\text { lokasi tertentu yang strategis. }\end{array}$ & 0 & 8 & 6 & 45 & 41 & 100 \\
\hline 3 & $\begin{array}{l}\text { Bank Syariah Mandiri } \\
\text { melakukan promosi melalui } \\
\text { iklan televisi produk tabungan } \\
\text { haji (mabrur). }\end{array}$ & 0 & 3 & 9 & 49 & 39 & 100 \\
\hline 4 & $\begin{array}{l}\text { Promosi Penjualan (Sales } \\
\text { Promotion) Syariah Mandiri } \\
\text { Bank atau } \\
\text { memberikan hadiah } \\
\text { cinderamata dari untuk anda. }\end{array}$ & 0 & 0 & 11 & 49 & 40 & 100 \\
\hline 5 & $\begin{array}{l}\text { Karyawan Bank Syariah Mandiri } \\
\text { memberikan dorongan kepada } \\
\text { anda untuk menggunakan } \\
\text { produk tabungan haji (mabrur). }\end{array}$ & 0 & 0 & 10 & 54 & 36 & 100 \\
\hline & $\begin{array}{l}\text { Hubungan Masyarakat (Public } \\
\text { Relations) }\end{array}$ & & & & & \\
\hline
\end{tabular}


Makhdaleva H, Ade Sofyan M: Pengaruh Promosi...

\begin{tabular}{|c|c|c|c|c|c|c|c|}
\hline 6 & $\begin{array}{l}\text { Bank Syariah Mandiri mengikuti } \\
\text { pameran di pusat perbelanjaan. }\end{array}$ & 0 & 2 & 11 & 55 & 32 & 100 \\
\hline \multirow[t]{2}{*}{7} & $\begin{array}{l}\text { Bank Syariah Mandiri mengikuti } \\
\text { kegiatan-kegiatan amal di } \\
\text { lingkungan sekitar lokasi bank. }\end{array}$ & 0 & 2 & 7 & 53 & 38 & 100 \\
\hline & \multicolumn{7}{|l|}{$\begin{array}{l}\text { Pemasaran Langsung (Direct } \\
\text { Marketing) }\end{array}$} \\
\hline 8 & $\begin{array}{l}\text { Bank Syariah Mandiri } \\
\text { mempunyai web yang berisi net } \\
\text { banking. }\end{array}$ & 0 & 4 & 10 & 52 & 34 & 100 \\
\hline \multicolumn{2}{|r|}{ Total } & 0 & 2,4 & 8,9 & 51,4 & 37,4 & 100 \\
\hline
\end{tabular}

\section{Distribusi Jawaban Responden Mengenai Kepercayaan (X2).}

Variabel (X2) pada penelitian ini diukur melalui 8 pertayaan yang disebarkan ke 100 responden dan mempresentasikan indikator-indikator dari variabel tersebut. Hasil tanggapan terhadap kepercayaan dijelaskan pada tabel berikut:

\begin{tabular}{|c|l|c|c|c|c|c|c|c|}
\hline No & \multicolumn{1}{|c|}{ KEPERCAYAAN } & STS & TS & N & S & SS & Total \\
\hline & Kemampuan (Ability) & \multicolumn{5}{|l|}{} \\
\hline 1 & $\begin{array}{l}\text { Mampu mennyediakan produk } \\
\text { dan jasa yang dibutuhkan. }\end{array}$ & 0 & 0 & 1 & 59 & 40 & 100 \\
\hline 2 & $\begin{array}{l}\text { Memiliki pengalaman sehingga } \\
\text { dapat dipercaya. }\end{array}$ & 0 & 0 & 1 & 56 & 43 & 100 \\
\hline 3 & $\begin{array}{l}\text { Mampu menciptakan trasaksi } \\
\text { yang aman. }\end{array}$ & 0 & 0 & 5 & 49 & 46 & 100 \\
\hline 4 & $\begin{array}{l}\text { Kebaikan Hati (Benevolence) } \\
\text { Memiliki perhatian untuk } \\
\text { memberikan pelayanan terbaik }\end{array}$ & 0 & 0 & 1 & 49 & 50 & 100 \\
\hline 5 & $\begin{array}{l}\text { Memiliki itikad baik untuk } \\
\text { memberikan kepuasan. }\end{array}$ & 0 & 0 & 3 & 51 & 46 & 100 \\
\hline 6 & $\begin{array}{l}\text { Integritas (Integrity) } \\
\text { Memiliki kemauan untuk } \\
\text { memberikan keuntungan. }\end{array}$ & 0 & 0 & 3 & 52 & 45 & 100 \\
\hline 7 & $\begin{array}{l}\text { Memenuhi apa yang diinginkan } \\
\text { nasabah. }\end{array}$ & 0 & 0 & 2 & 60 & 38 & 100 \\
\hline 8 & $\begin{array}{l}\text { Berkata jujur dan tidak } \\
\text { menyembunyikan informasi } \\
\text { penting bagi nasabah. }\end{array}$ & 0 & 0 & 1 & 58 & 41 & 100 \\
\hline
\end{tabular}


Islamiconomic: Jurnal Ekonomi Islam

Vol.8 No.1 Januari - Juni 2017

\begin{tabular}{|l|l|l|l|l|l|l|l|}
\hline Total & 0 & 0 & 2,2 & 54,3 & 43,7 & 100 \\
\hline
\end{tabular}

\section{Distribusi Jawaban Responden Mengenai Kesadaran Merek (X3).}

Variabel (X3) pada penelitian ini diukur melalui 6 pertayaan yang disebarkan ke 100 responden dan mempresentasikan indikator-indikator dari variabel tersebut. Hasil tanggapan terhadap produktivitas kerja dijelaskan pada tabel berikut:

\begin{tabular}{|c|c|c|c|c|c|c|c|}
\hline No & KESADARAN MEREK & STS & TS & $\mathbf{N}$ & $\mathbf{S}$ & SS & Total \\
\hline & $\begin{array}{l}\text { Tidak Menyadari Merek (Brand } \\
\text { Unaware) }\end{array}$ & & & & & & \\
\hline \multirow[t]{2}{*}{1} & $\begin{array}{l}\text { Produk Tabungan Haji (Mabrur) } \\
\text { di Bank Syariah Mandiri tidak } \\
\text { diketahui sebelumnya. }\end{array}$ & 0 & 3 & 14 & 51 & 32 & 100 \\
\hline & $\begin{array}{l}\text { Pengenalan Merek (Brand } \\
\text { Recognition) }\end{array}$ & & & & & & \\
\hline \multirow[t]{2}{*}{2} & $\begin{array}{l}\text { Mengetahui tentang adanya } \\
\text { produk Tabungan Haji (Mabrur) } \\
\text { di Bank Syariah Mandiri. }\end{array}$ & 0 & 5 & 15 & 49 & 31 & 100 \\
\hline & $\begin{array}{l}\text { Pengingatan Kembali Terhadap } \\
\text { Merek (Brand Recall) }\end{array}$ & & & & & & \\
\hline 3 & $\begin{array}{l}\text { Setelah waktu yang lama anda } \\
\text { dapat mengingat produk } \\
\text { Tabungan Haji (Mabrur) dengan } \\
\text { melihat spanduk di jalan. }\end{array}$ & 0 & 2 & 18 & 52 & 28 & 100 \\
\hline \multirow[t]{2}{*}{4} & $\begin{array}{l}\text { Pembicaraan anda dengan } \\
\text { nasabah lain atau kerabat } \\
\text { keluarga membuat anda ingat } \\
\text { produk Tabungan Haji (Mabrur). }\end{array}$ & 0 & 7 & 9 & 54 & 30 & 100 \\
\hline & Puncak Pikiran (Top of Mind) & & & & & & \\
\hline 5 & $\begin{array}{l}\text { Yang pertama kali diingat saat } \\
\text { akan pergi haji adalah Tabungan } \\
\text { Haji (Mabrur) Bank Syariah } \\
\text { Mandiri. }\end{array}$ & 0 & 7 & 13 & 53 & 27 & 100 \\
\hline \multirow[t]{2}{*}{6} & $\begin{array}{l}\text { Yakin memilih produk Tabungan } \\
\text { Haji (Mabrur) setelah menimbang } \\
\text { produk Tabungan haji Bank lain } \\
\text { dengan Tabungan Haji (Mabrur) } \\
\text { Bank Syariah Mandiri. }\end{array}$ & 0 & 5 & 15 & 49 & 31 & 100 \\
\hline & Total & 0 & 4,9 & 14 & 51,4 & 29,9 & 100 \\
\hline
\end{tabular}


Makhdaleva H, Ade Sofyan M: Pengaruh Promosi...

4. Distribusi Jawaban Responden Mengenai Keputusan Pembelian (Y).

Variabel (Y) pada penelitian ini diukur melalui 6 pertayaan yang disebarkan ke 100 responden dan mempresentasikan indikator-indikator dari variabel tersebut. Hasil tanggapan terhadap produktivitas kerja dijelaskan pada tabel berikut:

\begin{tabular}{|c|c|c|c|c|c|c|c|}
\hline No & KEPUTUSAN PEMBELIAN & STS & TS & $\mathbf{N}$ & $\mathbf{S}$ & SS & Total \\
\hline & Pengenalan Masalah & & & & & & \\
\hline \multirow[t]{2}{*}{1} & $\begin{array}{l}\text { Memiliki tabungan haji (Mabrur) } \\
\text { di Bank Syariah Mandiri guna } \\
\text { memenuhi kebutuhan dalam pergi } \\
\text { haji. }\end{array}$ & 0 & 0 & 9 & 52 & 39 & 100 \\
\hline & Pencarian Informasi & & & & & & \\
\hline 2 & $\begin{array}{l}\text { Sebelum menabung di tabungan } \\
\text { haji (Mabrur) Bank Syariah } \\
\text { Mandiri, nasabah mendapatkan } \\
\text { informasi yang berkenaan dengan } \\
\text { Bank Syariah Mandiri dari orang- } \\
\text { orang disekitar. }\end{array}$ & 0 & 3 & 14 & 54 & 29 & 100 \\
\hline \multirow[t]{2}{*}{3} & $\begin{array}{l}\text { Aktif mencari informasi tentang } \\
\text { tabungan haji (Mabrur) di Bank } \\
\text { Syariah Mandiri baik dari meda } \\
\text { cetak atau elektronik. }\end{array}$ & 0 & 0 & 10 & 66 & 24 & 100 \\
\hline & Evaluasi Akternatif & & & & & & \\
\hline \multirow[t]{2}{*}{4} & $\begin{array}{l}\text { Pertimbangan memilih tabungan } \\
\text { haji (Mabrur) Bank Syariah } \\
\text { Mandiri seperti pelayanan yang } \\
\text { diberikan ketika melaksanakan } \\
\text { haji. }\end{array}$ & 0 & 1 & 14 & 47 & 38 & 100 \\
\hline & Keputusan Pembelian & & & & & & \\
\hline \multirow[t]{2}{*}{5} & $\begin{array}{l}\text { Merasa tepat memilih tabungan } \\
\text { haji (mabrur) di Bank Syariah } \\
\text { Mandiri. }\end{array}$ & 0 & 0 & 14 & 53 & 33 & 100 \\
\hline & Keputusan Pasca Pembelian & & & & & & \\
\hline \multirow[t]{2}{*}{6} & $\begin{array}{l}\text { Merasa puas karena kebutuhan } \\
\text { akan menabung tabungan haji } \\
\text { (mabrur) terpenuhi di Bank } \\
\text { Mandiri Syariah. }\end{array}$ & 0 & 0 & 9 & 52 & 39 & 100 \\
\hline & Total & 0 & 0.7 & 11.7 & 54 & 33,7 & 100 \\
\hline
\end{tabular}




\section{Hasil Analisis Data}

\section{Uji Asumsi Klasik}

\section{Uji Normalitas}

\section{a. Kurva Normalitas P-Plot}

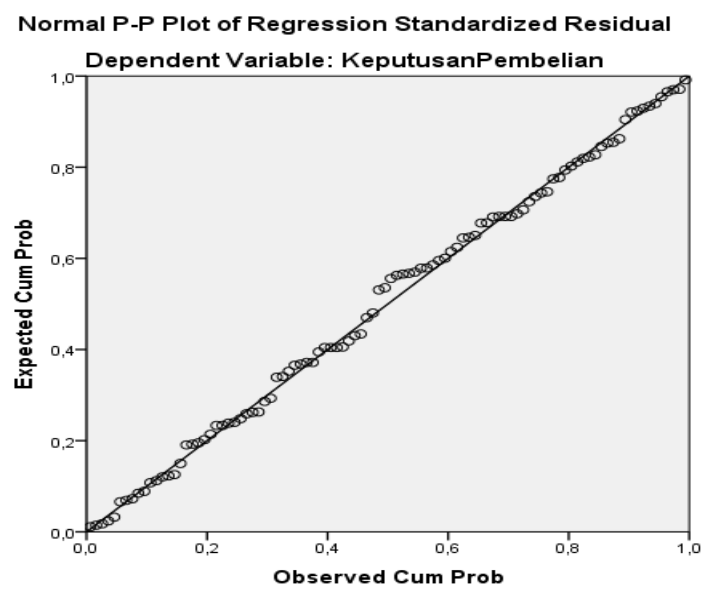

Berdasarkan hasil analisis data pada gambar di atas kurva normal p-plot, dapat disimpulkan bahwa dalam kurva normal p-plot terlihat titik menyebar di sekitar garis diagonal dan penyebarannya tidak terlalu jauh atau melebar. Berarti dari kurva ini menunjukkan bahwa model regresi sesuai asumsi normalitas dan layak digunakan.

\section{b. Statistik non-parametrik Kolmogrov-Smirnov (K-S)}

\begin{tabular}{|c|c|c|}
\hline & & $\begin{array}{l}\text { Unstandardized } \\
\text { Residual }\end{array}$ \\
\hline $\mathrm{N}$ & & 100 \\
\hline \multirow{3}{*}{ Normal Parameters ${ }^{\mathrm{a}, \mathrm{b}}$} & Mean & ,0000000 \\
\hline & Std. Deviation & 2,13592992 \\
\hline & Absolute & 057 \\
\hline \multirow[t]{2}{*}{ Most Extreme Differences } & Positive & 030 \\
\hline & Negative &,- 057 \\
\hline Kolmogorov-Smirnov Z & & ,568 \\
\hline Asymp. Sig. (2-tailed) & & ,903 \\
\hline
\end{tabular}

a. Test distribution is Normal.

b. Calculated from data. 
Makhdaleva H, Ade Sofyan M: Pengaruh Promosi...

Berdasarkan uji statistik normalitas di atas menunjukan nilai sig. (2-tailed) sebesar $0,903>0,05$, sehingga dapat disimpulkan data berdistribusi normal.

\section{Uji Multikolinearitas}

\begin{tabular}{|c|c|c|c|c|c|c|c|}
\hline \multirow[t]{2}{*}{ Model } & \multicolumn{2}{|c|}{$\begin{array}{l}\text { Unstandardized } \\
\text { Coefficients }\end{array}$} & \multirow{2}{*}{$\begin{array}{l}\text { Standardize } \\
\text { d } \\
\text { Coefficients } \\
\text { Beta }\end{array}$} & \multirow[t]{2}{*}{$\mathrm{T}$} & \multirow[t]{2}{*}{ Sig. } & \multicolumn{2}{|l|}{$\begin{array}{l}\text { Collinearity } \\
\text { Statistics }\end{array}$} \\
\hline & B & $\begin{array}{l}\text { Std. } \\
\text { Error }\end{array}$ & & & & Tolerance & VIF \\
\hline (Constant) & 2,515 & 3,310 & & ,760 & ,449 & & \\
\hline Promosi & 189 & ,062 & 273 & 3,065 & ,003 & ,858 & 1,165 \\
\hline 1 Kepercayaan & ,359 & ,091 & ,343 & 3,945 & ,000 & ,899 & 1,113 \\
\hline $\begin{array}{l}\text { KesadaranMere } \\
\mathrm{k}\end{array}$ & 149 & ,061 & 208 & 2,420 & ,017 & ,918 & 1,089 \\
\hline
\end{tabular}

a. Dependent Variable: KeputusanPembelian

Berdasarkan tabel diatas terlihat bahwa nilai tolerance $\geq 0,1$ dan nilai variance inflation factor (VIF) $\leq 10 / 10,00$ untuk setiap variabel, yang ditunjukkan dengan nilai tolerance promosi sebesar 0,858, kepercayaan sebesar 0,899, dan kesadaran merek sebesar 0,918. Selain itu nilai VIF untuk promosi sebesar 1,165, kepercayaan sebesar 1,113 dan kesadaran merek sebesar 1,089. karena variabel independen memiliki nilai tolerance lebih besar dari 0,1 dan nilai VIF kurang dari 10/10,00 dengan demikian, dapat disimpulkan bahwa model persamaan regresi tidak terdapat problem multiko dan dapat digunakan dalam penelitian ini. 


\section{Uji Heterokedastisitas}

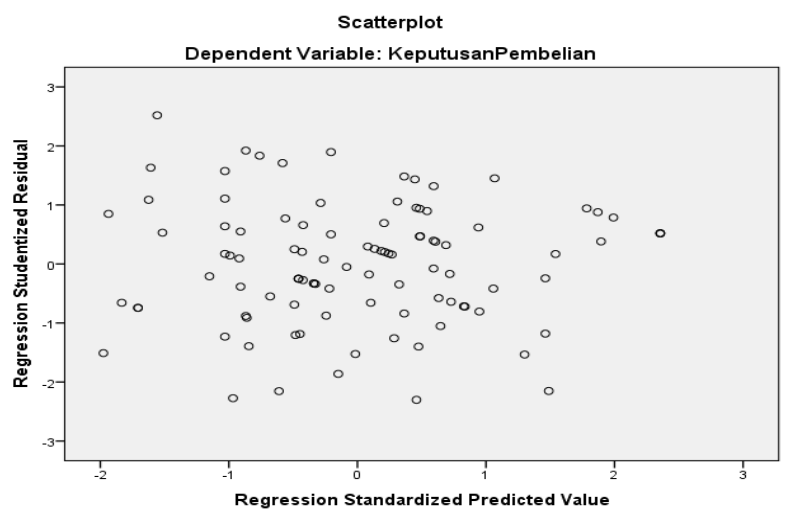

Berdasarkan gambar grafik scatterplot menunjukkan bahwa terlihat titik-titik menyebar secara acak (rondom) baik di atas maupun di bawah angka 0 pada sumbu Y. hal ini dapat disimpulkan bahwa tidak terjadi heteroskedastisitas pada model regresi.

\section{Uji Regresi Linier Berganda}

Coefficients

\begin{tabular}{|c|c|c|c|c|c|}
\hline \multirow[t]{2}{*}{ Model } & \multicolumn{2}{|c|}{$\begin{array}{l}\text { Unstandardized } \\
\text { Coefficients }\end{array}$} & \multirow{2}{*}{$\begin{array}{l}\text { Standardize } \\
\mathrm{d} \\
\text { Coefficients } \\
\text { Beta }\end{array}$} & \multirow[t]{2}{*}{$\mathrm{T}$} & \multirow[t]{2}{*}{ Sig. } \\
\hline & B & $\begin{array}{l}\text { Std. } \\
\text { Error }\end{array}$ & & & \\
\hline (Constant) & 2,515 & 3,310 & & ,760 & ,449 \\
\hline Promosi & , 189 & ,062 & ,273 & 3,065 & ,003 \\
\hline 1 Kepercayaan & ,359 & ,091 & ,343 & 3,945 & ,000 \\
\hline $\begin{array}{l}\text { KesadaranMere } \\
\text { k }\end{array}$ & ,149 & ,061 & ,208 & 2,420 & ,017 \\
\hline
\end{tabular}

a. Dependent Variable: KeputusanPembelian.

Interpretasi dari persamaan regresi di atas adalah sebagai berikut:

a. Nilai konstanta (a) sebesar 2,515 menyatakan bahwa jika tidak ada perubahan pada variabel-variabel independen maka keputusan nasabah menggunakan produk tabungan haji (mabrur) $=2,515$ (Purwanto dan Sulistyatuti, 2017:206).

b. Nilai koefisien regresi pada variabel promosi bernilai positif. Maka dapat diartikan bahwa apabila pengaruh promosi meningkat maka akan 
Makhdaleva H, Ade Sofyan M: Pengaruh Promosi...

meningkatkan keputusan nasabah menggunakan produk tabungan haji (mabrur) Bank Syariah Mandiri KCP. Sawangan Kota Depok.

c. Nilai koefisien regresi pada variabel kepercayaan bernilai positif. Maka dapat diartikan bahwa apabila pengaruh kepercayaan meningkat maka akan meningkatkan keputusan nasabah menggunakan produk tabungan haji (mabrur) Bank Syariah Mandiri KCP. Sawangan Kota Depok.

d. Nilai koefisien regresi pada variabel kesadaran merek bernilai positif. Maka dapat diartikan bahwa apabila pengaruh kesadaran merek meningkat maka akan meningkatkan keputusan nasabah menggunakan produk tabungan haji (mabrur) Bank Syariah Mandiri KCP. Sawangan Kota Depok.

\section{Uji Hipotesis}

\section{Uji Parsial (t)}

\begin{tabular}{|c|c|c|c|c|c|}
\hline \multirow[t]{2}{*}{ Model } & \multicolumn{2}{|c|}{$\begin{array}{l}\text { Unstandardized } \\
\text { Coefficients }\end{array}$} & \multirow{2}{*}{$\begin{array}{l}\text { Standardized } \\
\text { Coefficients } \\
\text { Beta }\end{array}$} & \multirow[t]{2}{*}{$\mathrm{T}$} & \multirow[t]{2}{*}{ Sig. } \\
\hline & B & $\begin{array}{l}\text { Std. } \\
\text { Error }\end{array}$ & & & \\
\hline (Constant) & 2,515 & 3,310 & & ,760 & ,449 \\
\hline Promosi & ,189 &, 062 & ,273 & 3,065 & 003 \\
\hline Kepercayaan & ,359 & ,091 & 343 & 3,945 & 000 \\
\hline KesadaranMerek & 149 & 061 & ,208 & 2,420 & 017 \\
\hline
\end{tabular}

a. Dependent Variable: KeputusanPembelian

a. Pengaruh Promosi $\left(\mathrm{X}_{1}\right)$ terhadap Keputusan Pembelian (Y)

Ho : $\beta 1=0$; tidak terdapat pengaruh antara promosi terhadap keputusan menggunakanproduk tabungan haji (mabrur).

Ha : $\beta 1 \neq 0$; terdapat pengaruh antara promosi terhadap proses keputusan menggunakanproduk tabungan haji (mabrur).

Diketahui bahwa thitung promosi sebesar $(3,065)$, sedangkan tabel bisa dihitung $\mathrm{a}=0,05$, karena digunakan hipotesis dua arah, ketika mencari $t_{\text {tabel, }}$ nilai a dibagi dua menjadi 0,025 serta $d f=n-2$, dimana $d f=100-2$ $=98$, dan didapat nilai tabel sebesar 1,98. Sehingga hasil yang di dapat 
Islamiconomic: Jurnal Ekonomi Islam Vol.8 No.1 Januari - Juni 2017

$t_{\text {hitung }}>t_{\text {tabel }}$ dimana $3,065>1,98$ dan variabel promosi mempunyai tingkat signifikansi sebesar 0,003. Hal ini mengindikasikan bahwa variabel promosi berpengaruh positif dan secara signifikan terhadap keputusan pembelian karena tingkat signifikansi yang dimiliki variabel promosi lebih kecil dari 0,05 yaitu 0,003 < 0,05. Maka dapat disimpulkan bahwa $\mathrm{H}_{0}$ ditolak dan $\mathrm{H}_{\mathrm{a}}$ diterima. Hal ini berarti promosi berpengaruh signifikan terhadap keputusan nasabah menggunakan tabungan haji (mabrur) Bank Syariah Mandiri.

Hasil penelitian ini sesuai dengan penelitian terdahulu yang dilakukan oleh Tambunan dan Nasution (2013) dimana faktor promosi berpengaruh positif tetapi tidak signifikan terhadap keputusan pembelian. Begitu juga dengan penelitian yang dilakukan Muanas dan Suherman (2014) dimana faktor promosi berpengaruh signifikan terhadap keputusan pembelian.

b. Pengaruh Kepercayaan $\left(\mathrm{X}_{2}\right)$ terhadap Keputusan Pembelian (Y) Ho : $\beta 2=0$; tidak terdapat pengaruh antara kepercayaan terhadap proses keputusan menggunakanproduk tabungan haji (mabrur). Ha : $\beta 2 \neq 0$; terdapat pengaruh antara kepercayaan terhadap proses keputusan menggunakanproduk tabungan haji (mabrur).

Diketahui bahwa $t_{\text {hitung }}$ kepercayaan sebesar $(3,945)$, sedangkan $t_{\text {tabel }}$ bisa dihitung $\mathrm{a}=0,05$, karena digunakan hipotesis dua arah, ketika mencari $t_{\text {tabel, }}$ nilai a dibagi dua menjadi 0,025 serta $\mathrm{df}=\mathrm{n}-2$, dimana $\mathrm{df}=$ $100-2=98$, dan didapat nilai $t_{\text {tabel }}$ sebesar 1,98 . Sehingga hasil yang di dapat $t_{\text {hitung }}>t_{\text {tabel }}$ dimana $3,945>1,98$ dan variabel kepercayaan mempunyai tingkat signifikansi sebesar 0,000. Hal ini mengindikasikan bahwa variabel kepercayaan berpengaruh positif dan secara signifikan terhadap keputusan pembelian karena tingkat signifikansi yang dimiliki variabel promosi lebih kecil dari 0,05 yaitu 0,000<0,05. Maka dapat disimpulkan bahwa $\mathrm{H}_{0}$ ditolak dan $\mathrm{H}_{\mathrm{a}}$ diterima. Hal ini berarti 
Makhdaleva H, Ade Sofyan M: Pengaruh Promosi...

kepercayaan berpengaruh signifikan terhadap keputusan nasabah menggunakan tabungan haji (mabrur) Bank Syariah Mandiri.

Hasil penelitian ini sesuai dengan penelitian terdahulu yang dilakukan oleh Mahkota., dkk (2014) dimana faktor kepercayaan berpengaruh signifikan terhadap keputusan pembelian. Begitu juga dengan penelitian yang dilakukan Yulianti., dkk (2016) dimana faktor kepercayaan berpengaruh signifikan terhadap keputusan pembelian.

c. Pengaruh Kesadaraan Merek $\left(\mathrm{X}_{3}\right)$ terhadap Keputusan Pembelian (Y) Ho : $\beta 3=0$; tidak terdapat pengaruh antara kesadaran merek terhadap proses keputusan menggunakanproduk tabungan haji (mabrur).

Ha : $\beta 3 \neq 0$; terdapat pengaruh antara kesadaran merek terhadap proses keputusan menggunakanproduk tabungan haji (mabrur).

Diketahui bahwa thitung kesadaran merek sebesar $(3,420)$, sedangkan $t_{\text {tabel }}$ bisa dihitung a $=0,05$, karena digunakan hipotesis dua arah, ketika mencari $t_{\text {tabel, }}$ nilai a dibagi dua menjadi 0,025 serta $\mathrm{df}=\mathrm{n}-2$, dimana $\mathrm{df}=$ $100-2=98$, dan didapat nilai $t_{\text {tabel }}$ sebesar 1,98 . Sehingga hasil yang di dapat $t_{\text {hitung }}>t_{\text {tabel }}$ dimana $3,420>1,98$ dan variabel kesadaran merek mempunyai tingkat signifikansi sebesar 0,017. Hal ini mengindikasikan bahwa variabel promosi berpengaruh positif dan secara signifikan terhadap keputusan pembelian karena tingkat signifikansi yang dimiliki variabel promosi lebih kecil dari 0,05 yaitu 0,017<0,05. Maka dapat disimpulkan bahwa $\mathrm{H}_{0}$ ditolak dan $\mathrm{H}_{\mathrm{a}}$ diterima. Hal ini berarti kesadaran merek berpengaruh signifikan terhadap keputusan nasabah menggunakan tabungan haji (mabrur) Bank Syariah Mandiri.

Hasil penelitian ini sesuai dengan penelitian terdahulu yang dilakukan oleh Dharma dan Sukaatmadja (2015) dimana faktor kesadaran merek berpengaruh positif dan signifikan terhadap keputusan pembelian. Begitu juga dengan penelitian yang dilakukan Hidayah dan Prabawani (2016) dimana faktor kesadaran merek berpengaruh signifikan terhadap keputusan pembelian. 
Islamiconomic: Jurnal Ekonomi Islam

Vol.8 No.1 Januari - Juni 2017

\section{Uji Simultan (F)}

\begin{tabular}{|c|c|c|c|c|c|}
\hline Model & Sum of Squares & Df & Mean Square & $\mathrm{F}$ & Sig. \\
\hline Regression & 240,583 & 3 & 80,194 & 17,04 &, $000^{\mathrm{b}}$ \\
\hline Residual & 451,657 & 96 & 4,705 & & \\
\hline Total & 692,240 & 99 & & & \\
\hline
\end{tabular}

a. Dependent Variable: KeputusanPembelian

b. Predictors: (Constant), KesadaranMerek, Kepercayaan, Promosi

Pada tabel di atas dari hasil uji Anova atau uji F dapat dilihat berdasarkan data diatas didapatkan nilai $\mathrm{f}_{\text {hitung }} 17,045$, sedangkan $\mathrm{f}_{\text {tabel }}$ dalam penelitian ini dimana df1 $=\mathrm{k}-1$, dan df2 $=\mathrm{n}-\mathrm{k}$, dimana dalam penelitian ini jumlah variabel independent 3 dan variabel dependent 1 serta jumlah sampel penelitian ini sebanyak 100 responden, sehingga df1 $=4-1=3$ dan df $2=$ $100-4=96$, dan dapat dilihat pada $\mathrm{f}_{\text {tabel }}$ pada penelitian ini adalah 2,70, sehingga dapat disimpulkan 17,045 > 2,70 dan probabilitas signifikansi pada penelitian ini $0,000<0,05$, maka dapat disimpulkan $\mathrm{H}_{0}$ ditolak dan $\mathrm{H}_{\mathrm{a}}$ diterima, bahwa ketiga variabel promosi, kepercayaan dan kesadaran merek secara bersama sama atau simultan berpengaruh terhadap keputusan nasabah.

d. Pengaruh Promosi, Kepercayaan dan Kesadaran Merek terhadap Keputusan Pembelian.

Ho : $\beta 1,2,3=0$; tidak terdapat pengaruh antara promosi, kepercayaan, dan kesadaran merek terhadap proses keputusan menggunakanproduk tabungan haji (mabrur).

Ha : $\beta 1,2,3 \neq 0$; terdapat pengaruh antara promosi, kepercayaan, dan kesadaran merek terhadap proses keputusan menggunakanproduk tabungan haji (mabrur). 
Makhdaleva H, Ade Sofyan M: Pengaruh Promosi...

\section{Uji Koefisien Determinasi $\left(R^{2}\right)$}

\begin{tabular}{|c|c|c|c|c|}
\hline \multicolumn{5}{|c|}{ Model Summaryb } \\
\hline Model & $\mathrm{R}$ & R Square & \begin{tabular}{|l} 
Adjusted R \\
Square
\end{tabular} & $\begin{array}{l}\text { Std. Error of the } \\
\text { Estimate }\end{array}$ \\
\hline 1 &, $590^{\mathrm{a}}$ & ,348 & ,327 & 2,16905 \\
\hline
\end{tabular}

a. Predictors: (Constant), KesadaranMerek, Kepercayaan, Promosi

b. Dependent Variable: KeputusanPembelian

Tabel di atas menunjukkan nilai Adjusted $R$ Square sebesar 0,327 atau 32,7\%, ini menunjukkan bahwa variabel keputusan pembelian yang dapat dijelaskan oleh variabel promosi, kepercayaan dan kesadaran merek adalah sebesar $32,7 \%$. Sedangkan sisanya sebesar 0,673 atau $67,3 \%$ variabel yang tidak diteliti oleh penulis.

\section{Penutup}

\section{Kesimpulan}

Penelitian ini bertuuan untuk mengetahui pengaruh promosi, kepercayaan dan kesadaran merek terhadap keputusan penggunaan tabungan haji (mabrur). Responden dalam penelitian ini berjumlah 100 orang nasabah tabungan haji (mabrur) di Bank Syariah Mandiri KCP. Sawangan Kota Depok. Berdasarkan data yang telah dikumpulkan dan pengujian yang telah dilakukan terhadap permasalahan dengan menggunakan analisis regresi linier berganda. Dengan demikian, dapat diambil kesimpulan sebagai berikut:

1. Promosi (X1) secara parsial berpengaruh terhadap proses keputusan menggunakan produk tabungan haji (mabrur) Bank Syariah Mandiri dengan nilai koefisien regresi sebesar 0,273.

2. Kepercayaan (X2) secara parsial berpengaruh terhadap proses keputusan menggunakan produk tabungan haji (mabrur) Bank Syariah Mandiri dengan nilai koefisien regresi sebesar 0,343.

3. Kesadaran merek (X3) secara parsial berpengaruh terhadap proses keputusan menggunakan produk tabungan haji (mabrur) Bank Syariah Mandiri dengan nilai koefisien regresi sebesar 0,208. 
Islamiconomic: Jurnal Ekonomi Islam

Vol.8 No.1 Januari - Juni 2017

4. Berdasarkan asil uji $\mathrm{F}$ variabel promosi, kepercayaan dan kesadaran merek secara simultan berpengaruh terhadap proses keputusan menggunakan produk tabungan haji (mabrur).

\section{Rekomendasi}

Berdasarkan hasil analisis di atas terhadap ketiga variabel independen, yaitu promosi, kepercayaan dan kesadaran merek terhadap satu variabel dependen, yaitu keputusan nasabah menggunakan produk tabungan haji (mabrur) pada Bank Syariah Mandiri KCP. Sawangan Kota Depok, maka peneliti menyarankan beberapa hal sebagai berikut:

1. Bagi Bank Syariah Mandiri

Dari penelitian ini masih ditemukan kekurangan yang didapat dari Bank Syariah Mandiri kuhususnya pada variabel kesadaran merek.Dari variabel kesadaran merek pada indikator sebagai berikut:

a) Mengetahui tentang adanya produk Tabungan Haji (Mabrur) di Bank Syariah Mandiri.

Dari dimensi Pengenalan Merek (Brand Recognition) dan pada indikator mengetahui tentang adanya produk Tabungan Haji (Mabrur) di Bank Syariah Mandiri. Berdasarkan hasil dari analisis deskriptif 15\% responden menyatakan netral dan 5\% menyatakan tidak setuju. Dalam hal ini, kurangnya pengetahuan bahwa adanya produk tabungan haji pada Bank Syariah Mandiri, maka dari itu diperlukannya promosi yang lebih giat dilakukan oleh pihak Bank Syariah Mandiri, seperti membuat iklan serta menayangkan iklan tersebut di stasiun-stasiun televisi ternama agar dapat dilihat oleh banyak orang sehingga timbul ketertarikan nasabah untuk menggunakan produk tabungan haji (mabrur) Bank Syariah Mandiri khususnya pada KCP. Sawangan Kota Depok.

b) Setelah waktu yang lama anda dapat mengingat produk Tabungan Haji (Mabrur) dengan melihat spanduk di jalan.

Dari dimensi Pengingatan Kembali Terhadap Merek (Brand Recall) dan pada indikator setelah waktu yang lama anda dapat mengingat produk 
Makhdaleva H, Ade Sofyan M: Pengaruh Promosi...

Tabungan Haji (Mabrur) dengan melihat spanduk di jalan. Berdasarkan hasil dari analisis deskriptif $18 \%$ responden menyatakan netral dan $2 \%$ menyatakan tidak setuju. Dalam hal ini, Bank Syariah Mandiri sebaiknya membuat spanduk di tempat yang lebih terlihat dan banyak orang-orang yang berlalulalang. Atau lebih baik seperti di papan-papan reklame agar dapat lebih baik menarik perhatian sehingga dapat mengingatkan nasabah akan adanya produk tabungan haji (mabrur) Bank Syariah Mandiri khususnya KCP. Sawangan Kota Depok.

c) Yang pertama kali diingat saat akan pergi haji adalah Tabungan Haji (Mabrur) Bank Syariah Mandiri.

Dari dimensi puncak pikiran (top of mind) dan pada indikator yang pertama kali diingat saat akan pergi haji adalah Tabungan Haji (Mabrur) Bank Syariah Mandiri. Berdasarkan hasil dari analisis deskriptif 13\% responden menyatakan netral dan 7\% menyatakan tidak setuju. Dalam hal ini Bank Syariah Mandiri harus menjadikan produk tabungan haji (mabrur) berada di top of mind, yaitu posisi istimewa dimana suatu citra menjadi 'pimpinan' dari berbagai merek yang ada dalam ingatan atau pikiran seseorang. Upaya yang harus dilakukan adalah mengasosiasikan merek menjadi citra positif menurut konsumen dan membuat konsumen merasa bahwa merek kita merupakan jaminan kualitas, maka dari itu citra merek Bank Syariah Mandiri yang sudah cukup baik dimata nasabah haruslah di pertahankan bahkan ditingkatkan dengan cara memberikan perlayanan terbaik kepada setiap nasabah Bank Syariah Mandiri khususnya KCP. Sawangan Kota Depok.

d) Yakin memilih produk Tabungan Haji (Mabrur) setelah menimbang produk Tabungan haji Bank lain dengan Tabungan Haji (Mabrur) Bank Syariah Mandiri. Dari dimensi puncak pikiran (top of mind) dan pada indikator yakin memilih produk Tabungan Haji (Mabrur) setelah menimbang produk Tabungan haji Bank lain dengan Tabungan Haji (Mabrur) Bank Syariah Mandiri. Berdasarkan hasil dari analisis deskriptif $15 \%$ responden 
Islamiconomic: Jurnal Ekonomi Islam

Vol.8 No.1 Januari - Juni 2017

menyatakan netral dan 5\% menyatakan tidak setuju. Dalam hal ini, sebaiknya pegawai Bank Syariah Mandiri khususnya KCP. Sawangan Kota Depok agar memberikan pelayanan prima kepada setiap nasabahnya, yaitu memberikan layanan terbaik dengan mengutamakan kepedulian terhadap nasabah, agar nasabah yakin dan percaya dengan adanya service excellent yang diberikan minimal harus ada tiga hal yang dilakukan, yaitu peduli pada nasabah, melayani dengan tindakan terbaik dan memuaskan nasabah dengan berorientasi pada standar layanan tertentu kepada para nasabah Bank Syariah Mandiri khususnya KCP. Sawangan Kota Depok.

\section{Bagi Peneliti Selanjutnya}

Penelitian ini dapat menambah pengetahuan lebih mendalam terkait variabel promosi, kepercayaan dan kesadaran merek tidak hanya meneliti mengenai pengaruh variabel tersebut, tetapi meneliti mengenai perbandingan variabel pada area yang lebih luas khususnya di area bauran pemasaran yang belum diteliti seperti lokasi dan harga.

\section{Daftar Pustaka}

Aaker, D.A. “Managing Brand Equity”, The Free Press, New York 1991.

Ahmad Muanas dan Suherman "Pengaruh Produk, Harga dan Promosi Terhadap Keputusan Pembelian Mobil Buana Indomobil Trada" Jurnal Ilmu \& Riset Manajemen Vol. 3, No. 12 (2014).

Andy Putra Mahkota, Imam Suryadi dan Riyandi "Pengaruh Kepercayaan dan Kenyamanan Terhadap Keputusan Pembelian Online (Studi Pada Pelanggan Website Ride In)" Junal Administrasi Bisnis (JAB) Vol. 8, No. 2 Maret 2014.

Armayanti "Penerapan Metode Role Playing Untuk Meningkatkan HasilBelajar Siswa Pada Sub Materi Pokok Sistem Ekskresi Pada Manusia DiKelas XI IPA SMA Negeri 11 Medan"UNIMED: Medan 2011/2012.

Durianto, Darmadi dkk. "Brand Equity Ten, Strategi Memimpin Pasar" PT. Gramedia Pustaka Utama, Jakarta 2004.

Erwan Agus Purwanto dan Dyah Ratih Sulistyastuti "Metode Penelitian Kuantitatif : Untuk Administrasi Publik dan Masalah-masalah Sosial" Penerbit Gava Media, Yogyakarta, 2017. 
Makhdaleva H, Ade Sofyan M: Pengaruh Promosi...

Ghozali, Imam. "Aplikasi Analisis Multivariate dengan Program SPSS". Badan Penerbit Universitas Diponegoro, Semarang, 2016.

Kopalle dan Lehman. "The Effects of Advertised and Observed Quality on Expectation About New Product Quality", Journal of Marketing Research,Vol XXXII. P. 280290, 1995.

Kotler, P dan Kevin Lane Keller. "Manajemen pemasaran. Edisi 13 Jilid 1". Alih bahasa: Bob Sabran. Editor: Adi Maulana dan Wibi Hardani. Penerbit Erlangga: Jakarta 2009.

Kotler, Philip \& Keller, Kevin."Marketing Management”, 14th edition, Pearson Education Inc, Prentice Hall, 2012.

Kotler, Philip and Gary Armstrong. "Prinsip - prinsip Pemasaran. Edisi13. Jilid 1". Erlangga: Jakarta 2012.

Laely Hidayah dan Bulan Prabawani "Pengaruh Suku Bunga, Pelayanan dan Kesadaran Merek (Brand Awareness) Terhadap Keputusan Pengambilan KPR (Studi Pada Nasabah PT Bank Tabungan Negara KC. Semarang)" 2016.

Macdonald, Emma, Sharp, Byron. "Management Perceptions of the Importance of Brand Awareness as an Indication of Advertising Effectiveness" Marketing Bulletin, 14, Article 2. Reprinted from Marketing Research On-Line, 1996, 1, 115 (2003).

Monang Ranto Tambunan dan Inggrita Gusti Sari Nasution "Analisis Faktor-faktor Yang Mempengaruhi Keputusan Nasabah Menabung di Bank BCA Kota Medan (Studi Kasus Etnis Cina)" Jurnal Ekonomi dan Keuangan Vol.1, No.3, Februari 2013.

Ngakan Putu Surya Adi Dharma dan I Putu Gde Sukaatmadja "Pengaruh Citra Merek, Kesadaran Merek, dan Kulitas Produk Terhadap Keputusan Membeli Produk Apple" E-Jurnal Manajemen Unud, Vol. 4, No.10, 3228-3255 ISSN:2302-8912. 2015.

Rangkuti, Freddy "Analisis SWOT Teknik Membedah Kasus Bisnis". PT Gramedia Pustaka Utama : Jakarta, 2010.

Rasyid, Sulaiman “Fiqih Islam" Sinar Baru : Bandung 2007.

Rika Yulianti, Marijati Sangen dan Ahmad Rivani "Pengaruh Nilai-nilai Agama, Kualitas Layanan, Promosi, dan Kepercayaan Terhadap Keputusan Menjadi Nasabah Bank Syariah di Banjarmasin" Jurnal Wawasan Manajemen, Vol. 4, Nomor 2, Juni 2016. 
Islamiconomic: Jurnal Ekonomi Islam

Vol.8 No.1 Januari - Juni 2017

Sugiono, "Metode Penelitian Pendidikan (Pendekatan Kuantitatif, Kualitatif, dan R\&D)" Bandung: Alfabeta 2011.

Sugiyono, “Metode Penelitian Kuantitatif Kualitatif dan R\&D”, Alfabeta, Bandung, 2015.

Suhardi, Gunarto, 2006 "Faktor-faktor yang Mempengaruhi Kepercayaan dan Loyalitas NasabahPerbankan di Surabay” Jurnal Kinerja Vol. 10 No. 1 tahun 2006.

Sunarto. “Manajemen Pemasaran 2", Adityamedia: Yogyakarta 2006.

Syukriyah, Tika "Strategi Promosi PT. Lintas Iskandaria Tours Dalam Meningkatkan Jumlah Jama'ah Umrah" Repository.uin.ac.id : Jakarta 2015.

Uslu Merih Otker, Saad Jasim, Antonette Arvai, Jatinder Bewtra \&Nihar Biswas " $A$ Survey of Occurrence and Risk Assessment of Pharmaceutical Substances in the Great Lakes Basin" 2013.

\section{Internet}

www.bisnisfranchiseonline.com, "Daftar Bank Dengan Program Tabungan Haji”, http://www.bisnisfranchiseonline.com/2015/12/daftar-bank-denganprogram-tabungan-haji.html. Diakses 4 Januari 2017.

www.republika.co.id, Erik Purnama Putra, "Persentase Umat Islam di Indonesia Jadi 85 Persen", 9-1-2016, http://nasional.republika.co.id/berita/nasional/umum/16/01/09/o0ow4v33 4-persentase-umat-islam-di-indonesia-jadi-85-persen. Diakses 11 Januari 2017.

www.republika.co.id, Fuji Pratiwi "BSM Hentikan Dana Talangan Haji Sejak 2014", 53-2016, http://www.republika.co.id/berita/ekonomi/syariahekonomi/16/03/05/o3kmoi394-bsm-hentikan-dana-talangan-haji-sejak2014. Diakses 12 Januari 2017.

www.syariahmandiri.co.id, "Tabungan Mabrur BSM", https://www.syariahmandiri.co.id/2010/05/tabungan-mabrur-bsm-2/. Diakses 11 Januari 2017.

www.syariahmandiri.co.id, Laporan Keuangan http://www.syariahmandiri.co.id/wpcontent/uploads/2010/03/AR-BSM-2015-Lap-Manajemen.pdf. Diakses 1 April 2017 